\title{
ТИПЫ И ГЕНЕЗИС СТРУКТУР С АНОМАЛЬНЫМ РАЗРЕЗОМ БАЖЕНОВСКОЙ СВИТЫ
}

Обрядчиков О.C.

(РГУ пефти и газа)

Баженовкая свита занимает особое положение в строении осадочного чехла ЗападноСибирской нефтегазоносной провинции. На сейсмических временных разрезах к кровле её приурочен наиболее чётко прослеживаемый в регионе опорный отражающий горизонт Б.

В конце позднекорской эпохи при интенсивном прогибании территории происходило накопление конденсированнных осадков с очень высокой концентрацией органического вещества. В отдельных прослоях она достигала $30-50 \%(1,2,3)$. Мощность отложений баженовской свиты относительно выдержана по площади и составляет 20-30 м за исключением отдельных локальных участков, в пределах которых отмечаются аномально большие значения - до 50-ти и даже $120 \mathrm{M}$.

Отличительной особенностью баженовской свиты является развитие участков с аномальным разрезом, когда в составе появляются песчаноалевролито-глинистые породы, а мощность свиты возрастает на $100 \%$ и более.

Существует несколько точек зрения на генезис зтих участков с аномальным разрезом баженовской свиты (АРБ). В основном, они сводятся к предположениям:

о существовании оползневых дислокаций с внедрением ачимовских осадков, поскольку петрографо-минералогический состав песчаников и алевролитов в АРБ сходен с ачимовскими ( );

- более широком стратитрафическом объёме баженовской свиты с последовательным включением глубоководных аналогов ачимовских отложений по мере продвижения клиноформ нижнемеловьх отложений к центру палеобассейна (1);

о развитин псевдодиапировых илк, как их называл П.П. Иванчук, гидровулканических образований;

о напичии турбидитных или других придонных переносов терригенного материала, поступавшего в бассейн с востока ().

Следует отметить, что АРБ встречается в двух видах: с нарушением сплошности пород (АРБр - аномальный разрез баженовской свиты с разломами) и с отсутствием разломов (АРБн - аномальный разрез баженовской свиты ненарушенный)

Породы АРБр по керну пробуренных скважин характеризуются значительной перемятостью, присутствуют зеркала скольжения. В противоположность им в АРБн отмечается субгоризонтальная слоистость и неплохая коррелируемость пластов. С этой аномальной частью баженовской свиты, содержащей песчано-алевролитовые прослои, связываются пласты серии Ю0. Их мощность составляет от первых единиц до 26 метров.

АРБн прослеживается в плане в виде субмеридионально ориентированных полос. Одна из них прослеживается в районе г. Когалым от Кечимовского месторождения на север до Северо-Ягунской площади. В зоне его распространения установлен участок с АРБр в районе скв.104 Кустового место- рождения.

Генезис АРБн не может быть объяснён седиментационными условиями бассейна осадконакопления. Скорее всего образование АРБн следует связывать с процессом воздушного переноса алевритов и пелитов в виде вулканических пеплов, что объясняет повышенное содержание кремнезёма, ити считать их золовыми осадками.

Генезис АРБр сложно объяснять оползневыми процессами. Ведь образование подобных структур происходит не на начальном этапе осаждения ачимовских пород, а после накопления их некоторой мошности. При этом в результате оползневых срывов не происходит нарушение пластов георгиевской свиты.

По-видимому, процесс образования АРБр связан с изменением температурного режима в баженовской свите. После перекрытия её ачимовскими отложениями мощностью от 40 до 60м температура в баженовской свите стала резко увеличиваться. Это привело к преобразованию содержащейся в ней органикн, повышению давления и в итоге - к взрыву. В образовавшуюся пустоту хлынули ачимовские осадки. Этим объясняется перемятость оєадков АРБр, ачимовская природа включений и сложная геометрия структуры при ненарушенности нижележащих пластов. Структуры АРБр предложено классифицировать как структуры взрывного типа.

\section{ЛИТЕРАТУРА}

Мкртиян O.M. - Новое в модели строения и формировакия баженовской свиты Западной Сибири. - "Нефтегазовая геология и геофизика", 1984, вып.7, с.1-6.

Мкртиян О.М., Гребнева И.Л., Филина С.И. - Региональное изучение нефтегазоносного клиноформенного аяимовского комплекса в Среднем Приобье- Сб. науч. тр. "Современные геофизические методы при решении задач нефтяной геологии". - М.: Наука, 1988 , с. $38-45$.

Филиппович Ю.В. - Типы и механизмы формирования аномальньгх разрезов баженовского горизогта и ачимовской толщи «Вестник недропользования», 1999. - №4. - С. 30-34. 